\title{
Growth and Development of Pinegrass in Interior British Columbia
}

\author{
DARRYL G. STOUT AND BARBARA BROOKE
}

\begin{abstract}
Pinegrass (Calamagrostis rubescens Buckl.) is an important source of forage on forested and clearcut ranges in interior British Columbia. The vegetative growth and development of this infrequently flowering grass was documented. This information is required to improve our understanding of pinegrass grazing resistance, and in turn, of its grazing management. Numbers of tillers $\mathbf{m}^{-2}$ and number of leaves per tiller were counted at intervals during the growing seasons of 1978 and 1979. Leaf blade area was measured at intervals during 1978 and 1979. Tiller height was recorded during 1978,1979 , and 1982, while shoot weight was recorded at intervals during 1982. Pinegrass had up to 4 leaves per tiller, but on average only 3.2 leaves were present by the time growth ceased in July. Total leaf blade area was reached in July, and is largely comprised of 2 leaves. Total leaf blade area $(y)$ was predicted from tiller height $(x): y=0.39375+0.051604 x+0.00419223 x^{2}\left(R^{2}=0.97\right)$. A large proportion of leaf blade area was dead by the end of July. Tiller weight reached a maximum in July; it increased during May to July owing to an increase in number of leaves, leaf area, and specific weight of leaves. Growth analysis indicated that net assimilation rate (NAR), and relative growth rate (RGR) were high in mid-May and then gradually decreased to zero in July. NAR and RGR of pinegrass appeared typical for $\mathrm{C}_{3}$ plants.
\end{abstract}

Pinegrass (Calamagrostis rubescens Buckl.) provides $50 \%$ of the forage production within the interior Douglasfir (Pseudotsuga menziesii Mirb.) zone of British Columbia (McLean et al. 1969), and about 6 million hectares of this zone are used for summer grazing (Tisdale and McLean 1957). Single year simulated grazing studies have shown that pinegrass is most sensitive to herbage removal during July (Freyman 1970, Stout et al. 1980). A study involving successive years of simulated grazing showed that stand vigor, measured as number of tillers $\mathrm{m}^{-2}$, decreased each year by an amount that depended upon the intensity of the herbage removal (Stout et al. 1981). Clipping biweekly during the summer growth period to a height of $5 \mathrm{~cm}$ caused the stand vigor to decrease by one-half after each year of clipping, whereas clipping biweekly during the summer growth period to a height of $10 \mathrm{~cm}$ caused the stand vigor to decrease by one-half only after 3.7 years. In British Columbia, pinegrass became unpalatable by mid-August (McLean 1967), and the quality of pinegrass was adequate for rapid growth of yearly steers or for maintaining weanling calves only until 1 August (McLean et al. 1969).

This study was conducted to characterize the growth and development of pinegrass. Such basic knowledge will increase our understanding of the simulated grazing studies and the forage quality studies that have already been conducted. In addition, this knowledge will allow better design of future grazing studies, and can be used directly by range managers. Flowering culm production, location of growing point, and clump basal area are frequently used by range managers to document growth. Since pinegrass is a rhizomatous and infrequently flowering species, this study was limited to vegetative growth characteristics.

Authors are research scientist and technican, Agriculture Canada, Range Research Station, 3015 Ord Road, Kamloops, B.C. V2B 8A9, Canada

Manuscript accepted September 27, 1984.

\section{Materials and Methods}

The study was conducted during 1978, 1979, and 1982. The site was adjacent to the Poison Creek site described earlier (Stout et al. 1980 ), $18 \mathrm{~km}$ north of Kamloops airport at $1,189 \mathrm{~m}$ elevation. Limited weather data for this site and a nearby site (Pass Lake) have been published (McLean et al. 1969, Stout et al. 1980). The soil is a Gray Luvisol (A.L. van Ryswyk personal communication) (Canadian Soil Survey Committee 1978) on glacial till material, with a high percentage of parent rock fragments in the profile (Tisdale and McLean 1957). The forest cover was a moderately open stand of trembling aspen (Populus tremuloides Dougl.), lodgepole pine (Pinus contorta Dougl.) and douglasfir. The major shrubs were birch-leaved spirca (Spirea betulifolia Pall.), rose (Rosa sp. L.), twinflower (Linnaea borealis L.), and creeping oregongrape (Berberis repens Lindl.). Pinegrass was the predominant graminoid and the major ground cover constituent. Forbs included broad-leaved lupine (Lupinus latifolius Agardh), heart-leaf arnica (Arnica curdifolia Hook.), cream-flowered peavine (Lathyrus ochroleucus Hook.) and wild strawberry (Fragaria virginiana Duchesne).

In 1978, 20 tillers within a $3 \times 6-\mathrm{m}$ area were randomly selected. On each collection date, height above the forest floor of these 20 tillers was measured. Twenty tillers of similar height were then selected from within the $3 \times 6-\mathrm{m}$ area, harvested, placed in plastic bags containing a little water, and transported to the laboratory on ice for leaf a rea and weight measurements. In 1979 individual tillers were taken at $1-\mathrm{m}$ intervals from a different starting point on a permanent transect on each date. Each tiller selected was the first one intercepted by a meter stick laid at right angles to the line at the predetermined point. The height of a selected tiller was measured and then the selected tiller was harvested and transported to the laboratory as in 1978. In 1982 six collection points chosen visually to represent the site were staked. Based on visual observations, a representative group of tiller tufts was taken from within a $0.5-\mathrm{m}$ radius. Twenty tillers were collected from each location on each date. All tillers in a tuft were taken before moving on to another tuft to get the total of 20 tillers. A tuft typically contained 6 tillers. The height of each tiller was recorded and then the tiller was harvested and transported to the laboratory.

Leaf blade area, a measure of photosynthetic area, was measured in 1978 and 1979. At the laboratory, a tiller was removed from the plastic bag, number of leaves were counted, and the blades were immediately removed from the tiller and mounted on paper. Pinegrass has 4 or 5 small rudimentary leaves that were excluded from our measurements. The lowest 3 or 4 rudimentary leaves do not extend above the litter layer and they become dry brown scales as the tiller matures. The upper 1 or 2 rudimentary leaves extend above the litter and may turn green. Leaves were numbered, starting with the lowest on the stem (the oldest) having a blade length greater than $1 \mathrm{~cm}$. Only the leaf blade area exerted from the sheath (of the preceding leaf) was measured. This included some immature leaves that were still rolled, so they were unrolled before being mounted. Leaves that were not at all exposed were discarded. In mounting, a $1.25 \mathrm{~cm}$ wide length of Magic (3M) transparent tape was laid on the working surface, adhesive side up, anchored at both ends. The pinegrass blade was placed on the tape, 
abaxial side down, then flattened out so that its entire surface was in contact with the tape. The tape bearing the leaf was then affixed to a labelled sheet of paper. $\Lambda$ s soon as they were prepared, the pages of mounted leaves were photocopied since leaves were observed to shrink and curl on drying. Therefore, the photocopies were considered to be a more reliable record of leaf blade area. A dot planimeter (Bruning areagraph chart no. 4850) was used for leaf area determination. Means of duplicate counts for each of 3 planimeter placements on each blade were converted to square centimeters. Total and senesced blade areas were determined for each leaf blade. For blade weight determination, the mounted blades were peeled off the tape, dried $24 \mathrm{~h}$ in an $80^{\circ} \mathrm{C}$ oven, and weighed. This measurement was done on the whole (exerted) blade and so included both live and senesced tissues.

Distribution of dry weight and percent dry matter within a tiller were determined in 1982. In the field the tiller was divided into 3 components. These were: "blade", all completely exerted blades over $1 \mathrm{~cm}$ in length, and the exerted portion of immature blades; "sheath", the foliage standing above the litter layer, excluding exerted blades and comprising sheaths, and blades $1 \mathrm{~cm}$ or less in length and all immature tissue enveloped in the sheaths; "subterranean tiller base", the base of the tiller, lying beneath the surface of the litter layer, comprising (the vegetative) stem, rudimentary basal leaves and leaf sheaths of aerial leaves. The length of the tiller base ranged from 1 to $3 \mathrm{~cm}$ depending upon its point of origin on the previous year's stem or on the rhizome, and on the depth of the litter layer. A bulk 20-tiller sample for each component was prepared for each of the 6 plots, weighed, oven-dried at $80^{\circ} \mathrm{C}$, and reweighed. Total tiller weight was calculated from the component wcights.

Growth analysis was done as described by Radford (1967). In 1978 and 1979, a relationship between leaf blade area and tiller height was established. In 1982, above ground level tiller dry weight $(\mathrm{W})$ was related to growth time $(\mathrm{t})$ by a second degree polynomial, $W=a+b t+c t^{2}$. Leaf blade area $(A)$ was estimated from tiller height and then related to growth time by a second degree polynomial, $A=a^{\prime}+b^{\prime} t+c^{\prime} t^{2}$. April 31 was arbitrarily chosen as day 0 since observations over several years indicate that snow melt typically occurs during the period April 24 to May 7. Net assimilation rate (NAR) at a particular time was then estimated using NAR $=1 / \mathrm{A} \mathrm{dW} / \mathrm{dt}$ and relative growth rate $(\mathrm{RGR})$ at a particular time was estimated using $R G R=1 / W \mathrm{dW} / \mathrm{dt}$. I eaf a rea ratio $(L A R)$ is defined by $L A R=R G R / N A R$. Average NAR was calculated using NAR $=\left[\left(W_{2}-W_{1}\right) /\left(A_{2}-A_{1}\right)\right]\left[\left(\ln A_{2}-\ln A_{1}\right) /\left(t_{2}-t_{1}\right)\right]$, and average $R G R$ was calculated using $R G R=\left(\ln W_{2}-\ln W_{1}\right) /\left(t_{2}-t_{1}\right)$.

Each experiment reported here had a completely random design. Statistical analysis involved calculating $\bar{x} \pm$ SE for a sample size of $\mathrm{n}$. Curve fitting was done using a computer program that does a least squares fit.

\section{Results}

\section{Growth of Tillers}

Number of pinegrass tillers $\mathrm{m}^{-2}$ remained constant from midMay to mid-July in 1978 and from mid-May to late-August in 1979 (Fig. 1). Tiller height increased in a quadratic fashion from May to July in all 3 years (Fig. 2). The derived polynomials indicated a maximum tiller height after $69 \mathrm{~d}$ in 1978, after $88 \mathrm{~d}$ in 1979, and after $84 \mathrm{~d}$ in 1982 . In 1982 tiller dry weight increased from mid-May to July (Fig. 3). Again, the experimental data were well described by a second degree polynomial. Using the polynomial it was calculated that maximum dry weight was reached after $86 \mathrm{~d}$. Increasing tiller dry weight was strongly correlated with increasing tiller height: $R^{2}=0.94, \mathrm{y}=4.0788+0.793458 \mathrm{x}+0.019526 \mathrm{x}^{2},(\mathrm{y}$ in $\mathrm{mg}$ and $x$ in $\mathrm{cm}$ ) and SEy. $x=6.16$.

\section{Growth of Tiller Components}

Dry weight of each tiller component increased from mid-May to July (Table 1). From May 18 to July 14, subterranean tiller bases

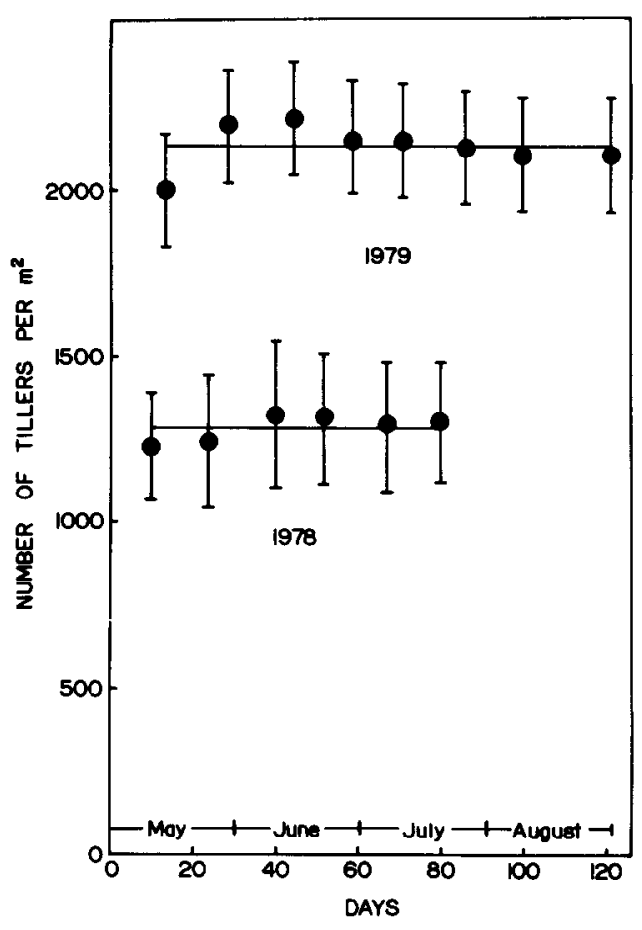

Fig. 1. Pinegrass tiller number during a growing season. Values are $\overline{\mathrm{x}} \pm S E$. In $1978 n=6$, and in $1979 n=24$.

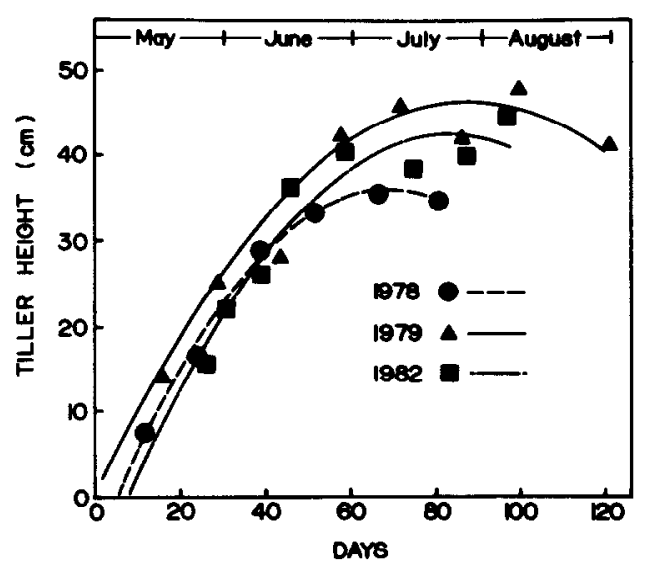

Fig. 2. Pinegrass tiller height (y) during a growing season ( $\mathrm{x}=$ days after April 31). In 1978 and 1979 the mean was calculated from 18 tillers, and in 1982 the mean was calculated from 120 tillers. The smooth curves are best fit second degree polynomials: for 1978, $y=-62.3+12.2 x-0.088 x^{2}$, $S E_{\mathrm{y} . \mathrm{x}}=11.3, R^{2}=0.99 ;$ for $1979, y=0.13+10.57 x-0.060 x^{2}, S E_{\mathrm{y} . \mathrm{x}}=25.8$, $R^{2}=0.95 ;$ and for $1982, y=-92.18+12.29 x-0.073 x^{2}, S E_{y . x}=37.20, R^{2}=$ 0.86 .

increased in weight by a factor of 2.1 , leaf sheaths by a factor of 4.0 , and leaf blades by a factor of 10.5 . On 18 May, leaf blades comprised $38 \%$ of total tiller dry weight, but on 14 July leaf blades accounted for $67 \%$ of total tiller dry weight. During the growing season, percent dry weight increased with tiller age and at any tiller age, all 3 components had about the same percent dry weight (data not shown).

Since leaf blades contained most of the tiller dry weight and provided the majority of the photosynthetic area of a tiller, leaf and leaf blade growth were studied in detail. Pinegrass tillers had only 3.2 leaves with a blade length greater than $1 \mathrm{~cm}$ by the time growth stopped in July (Fig. 4). Leaf number data as a function of 
Table 1. Distribution of dry weight within a pinegrass shoot during a season of growth at Poison Creek.

\begin{tabular}{|c|c|c|c|c|c|}
\hline \multirow{2}{*}{\multicolumn{2}{|c|}{ Date }} & \multirow{2}{*}{$\begin{array}{l}\text { No. of days } \\
\text { from May } 1\end{array}$} & \multicolumn{3}{|c|}{ Dry weight $/$ tiller $^{1}$ (mg) } \\
\hline & & & Leaf blade & Leaf sheath & Subterranean tiller base \\
\hline \multirow[t]{3}{*}{ May } & 18 & 18 & $4.57 \pm 0.86$ & $4.26 \pm 0.54$ & $3.17 \pm 0.47$ \\
\hline & 26 & 26 & $11.04 \pm 2.06$ & $6.34 \pm 0.83$ & $4.15 \pm 0.66$ \\
\hline & 31 & 31 & $16.03 \pm 2.51$ & $8.51 \pm 1.08$ & $5.06 \pm 0.46$ \\
\hline \multirow[t]{3}{*}{ June } & 8 & 39 & $18.20 \pm 2.16$ & $10.33 \pm 1.31$ & $5.57 \pm 0.50$ \\
\hline & 15 & 46 & $33.60 \pm 3.85$ & $15.64 \pm 1.79$ & $7.49 \pm 0.75$ \\
\hline & 28 & 59 & $42.18 \pm 2.45$ & $15.08 \pm 1.69$ & $7.87 \pm 0.76$ \\
\hline \multirow[t]{2}{*}{ July } & 14 & 75 & $47.85 \pm 10.44$ & $17.10 \pm 3.51$ & $6.79 \pm 1.33$ \\
\hline & 26 & 87 & $48.50 \pm 4.62$ & $16.84 \pm 1.53$ & $6.97 \pm 0.47$ \\
\hline Aug. & 5 & 97 & $47.72 \pm 6.37$ & $16.08 \pm 2.51$ & $7.63 \pm 0.62$ \\
\hline
\end{tabular}

IValues are $\bar{x} \pm$ SE from 6 samples, where each sample contained 20 tillers.

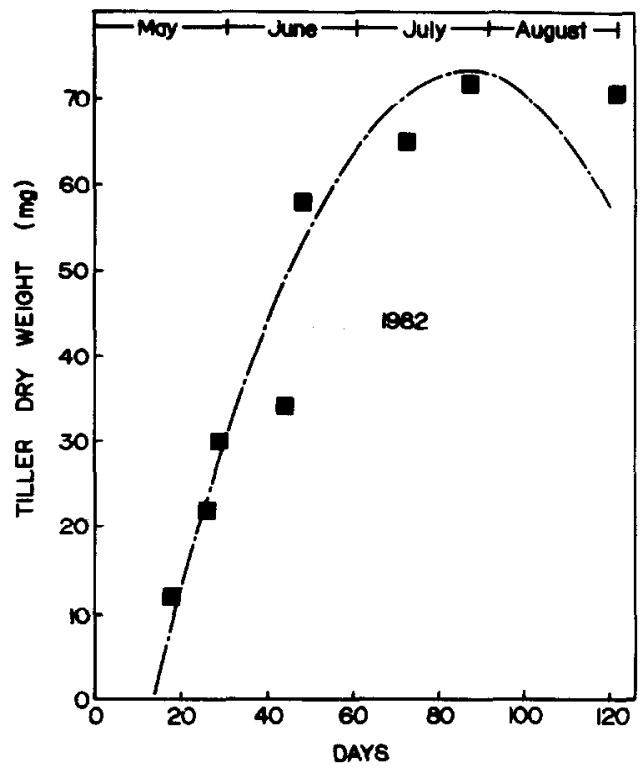

Fig. 3. Pinegrass tiller dry weight $(y)$ during $1982(x=$ days after 31 April . Each value is the mean for $n=6$ samples (each sample contained 20 tillers). The smooth curve is at least square fit second degree polynomial: $y=-29.8909+2.3891 x-0.013841 x^{2}, S E_{y \cdot x}=4.517, R^{2}=0.97$

time was well described by a second degree polynomial equation: $R^{2}=0.97$ for 1978 data and $R^{2}=0.83$ for 1979 data. The equation for 1978 indicated maximum number of leaves on day 62 , and the equation for 1979 indicated maximum number of leaves on day 86 .

Leaf numbers 1 and 4 (when it is present) contributed only a small amount to total tiller leaf blade area (Fig. 5). Leaves 2 and 3, on the other hand, had relatively large leaf blade areas and provided most of the total tiller leaf blade area.

Total leaf blade area increased in a quadratic fashion as a

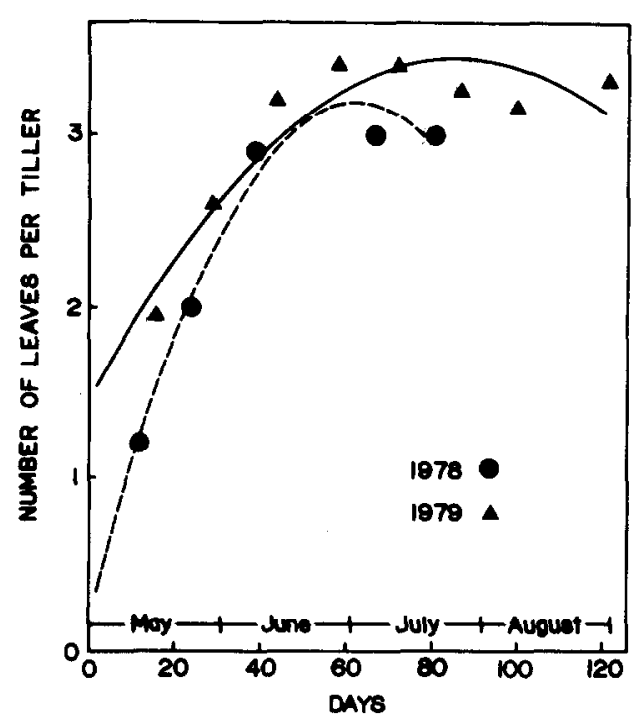

Fig. 4. Change in pinegrass leaf number (y) during a growing season ( $x=$ days after April 31). Experimental values are means from 18 tillers. Smooth curves are least square fit second degree polynomials: for $1978, y$ $=0.174461+0.0962124 x-0.00077027 x^{2}, S E_{\mathrm{y} . \mathrm{x}}=0.138, R^{2}=0.968$; and for $1979, y=1.43961+0.0463502 x-0.000268859 x^{2}, S E_{y \cdot x}=0.207, R^{2}=0.83$.

function of time. The polynomial equation indicated maximum tiller blade area on day 71 in 1978 and on day 92 in 1979 (Fig. 6). Beginning on about day 40 (June 9) parts of the leaf blades began to die (Fig. 6). This was observed as a color change from green to brown. Leaf margins and leaf tips were the first to change color; in addition, these symptoms occurred in older leaves first. By August 29 in 1979 about $50 \%$ of the total leaf blade area was dead.

Specific leaf weight was low in the spring and then increased to a maximum in July (Table 2). It then decreased during August as the

Table 2. Specific leaf weight $(\mathrm{mg} / \mathrm{cm})$ during the 1979 growing season for pinegrass at Poison Creek."

\begin{tabular}{|c|c|c|c|c|c|}
\hline \multirow{2}{*}{\multicolumn{2}{|c|}{ Date }} & \multirow[b]{2}{*}{1} & \multicolumn{3}{|c|}{ Leaf number (mg) } \\
\hline & & & 2 & 3 & 4 \\
\hline May & $\begin{array}{l}16 \\
29\end{array}$ & $\begin{array}{l}40 \pm 2(20) \\
49 \pm 2(19)\end{array}$ & $\begin{array}{l}35 \pm 1(15) \\
38 \pm 2(20)\end{array}$ & $47 \pm 4(11)$ & \\
\hline June & $\begin{array}{l}13 \\
27\end{array}$ & $\begin{array}{l}39 \pm 3(19) \\
60 \pm 5(15)\end{array}$ & $\begin{array}{l}41 \pm 2(20) \\
50 \pm 2(20)\end{array}$ & $\begin{array}{l}41 \pm 2(18) \\
50 \pm 2(29)\end{array}$ & $\begin{array}{l}44 \pm 1(2) \\
45 \pm 4(6)\end{array}$ \\
\hline July & $\begin{array}{l}11 \\
25\end{array}$ & $\begin{array}{l}54 \pm 3(18) \\
40 \pm 2(17)\end{array}$ & $\begin{array}{l}49 \pm 1(21) \\
51 \pm 2(21)\end{array}$ & $\begin{array}{l}53 \pm 1(21) \\
52 \pm 3(19)\end{array}$ & $\begin{array}{l}52 \pm 3(6) \\
48 \pm 4(5)\end{array}$ \\
\hline Aug. & $\begin{array}{r}8 \\
29\end{array}$ & $\begin{array}{l}48 \pm 3(20) \\
42 \pm 1(18)\end{array}$ & $\begin{array}{l}52 \pm 2(20) \\
41 \pm 1(20)\end{array}$ & $\begin{array}{l}60 \pm 3 \cdot(21) \\
52 \pm 2(20)\end{array}$ & $\begin{array}{l}65 \pm 5(4) \\
48 \pm 3(7)\end{array}$ \\
\hline
\end{tabular}

'Values are $\bar{x} \pm \mathrm{SE}(\mathrm{n})$. 


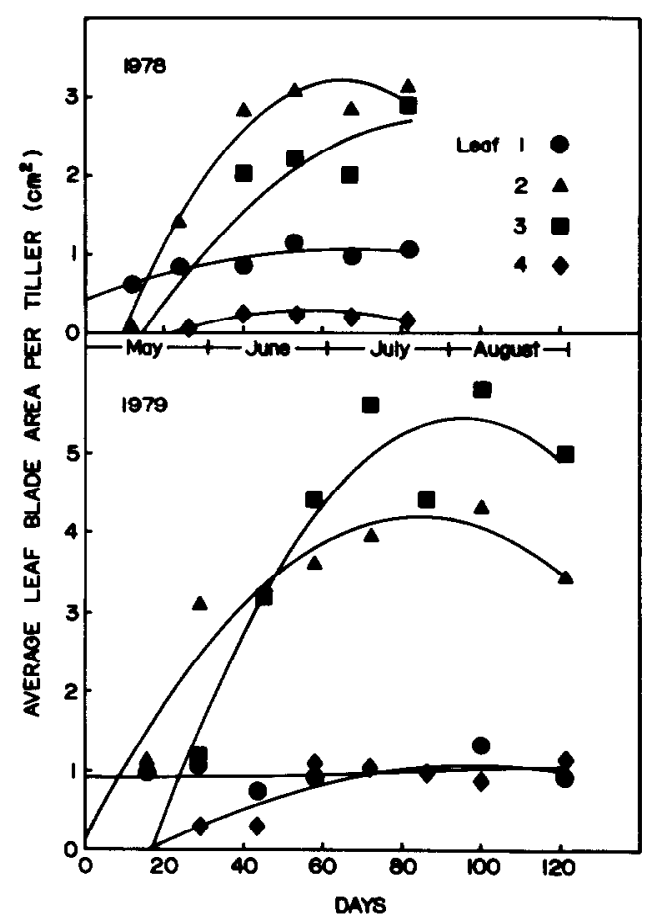

Fig. 5. Blade area (y) for individual pinegrass leaves during the growing season ( $x=$ days after April 31). Experimental data are means from 18 tillers. Smooth curves are least square fit second degree polynomials. Results from 1978 are as follows: for leaf $1, y=41.1103+1.89103 x-$ $0.0137338 x^{2}, S E_{y . x}=9.614, \mathbf{R}^{2}=0.75$; for leaf $2, y=-121.697+13.6209 x-$ $0.10505 x^{2}, S E_{y . x}=30.00, R^{2}=0.94$; for leaf $3, y=-117.912+8.65385 x-$ $0.0481801 x^{2}, S E_{y . x}=61.446, R^{2}=0.67$; and for leaf $4, y=-44.2068+$ $2.45745 x-0.0214611 x^{2}, S E_{y . x}=3.645, R^{2}=0.485$. Resultsfor 1979 are as follows: for leaf $1, y=89.94+0.0415 x+0.0008324 x^{2}, S E_{y . x} 18.7, R^{2}=0$; for leaf $2, y=11.7321+9.65109 x-0.0568348 x^{2}, S E_{y . x}=38.011, R^{2}=0.86$; for leaf 3, $y=-261.868+16.9016 x-0.088508 x^{2}, S E_{\mathrm{y} . \mathrm{x}}=103.523, R^{2}=$ 0.78 ; and for leaf $4, y=-44.9459+2.97677 x-0.0145881 x^{2}, S E_{y . x}=25.98$, $R^{2}=0.48$.

leaf tissue died (Fig. 6).

\section{Growth Analysis}

Both 1978 and 1979 total leaf blade areas were related to tiller height in a quadratic fashion (Fig. 7). Data from both years were used to calculate one polynomial equation, since this single equation described the data very well $\left(R^{2}=0.970\right)$. Using the relationship between leaf blade area and tiller height, growth analysis was done using tiller dry weight and calculated leaf areas from tiller height data collected in 1982. RGR and NAR both started out high in the spring (May) and decreased during the growth season (Fig. 8). In contrast, LAR started out low and increased during the growing season. RGR and NAR decreased to zero on day 85 (24 July ). During the period 20 May (day 20) to 20 July (day 81 ) the average $R G R$ was $0.029 \mathrm{~g} \mathrm{~g}^{-1} \mathrm{~d}^{-1}$, and the average NAR was 0.005 $\mathrm{mg} \mathrm{cm}{ }^{-1} \mathbf{d}^{-1}$.

\section{Discussion}

Grass yield from an area of land is a function of both the number of tillers and the weight of the tillers. Field observations of pinegrass have revealed that some new tiller development occurs during the fall. New tiller initiation is completed by early spring and additional tillers were not initiated during the period mid-May to August in any studies with ungrazed plants (Fig. 1). If, however, a pinegrass stand is grazed by cattle, then new tillers will be initiated during this period (unpublished data). The increase in tiller dry weight that occurred during the period mid-May to July was

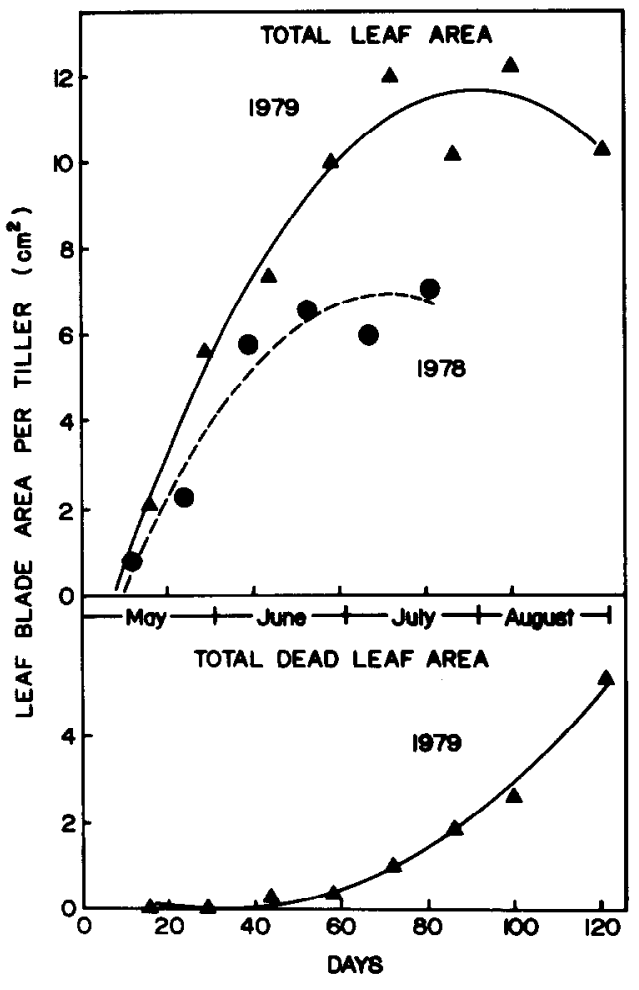

Fig. 6. Total and dead leaf blade area (y) for pinegrass during the growing season ( $x=$ days after April 31). Experimental values are means from 18 tillers. Smooth curves are least square fit second degree polynomials. For 1978 total leaf blade area, $y=-2.18506+0.256548 x-0.00180477 x^{2}, S E_{y . x}$ $=0.83, R^{2}=0.90$; and for 1979 total leaf blade area, $y=-2.152+$ $0.301889 x-0.0016428 x^{2}, S E_{y . x}=0.882, R^{2}=0.94$. For dead leaf blade area, $y=70.2364-4.36189 x+0.066388 x^{2}, S E_{y . x}=21.915, R^{2}=0.986$.

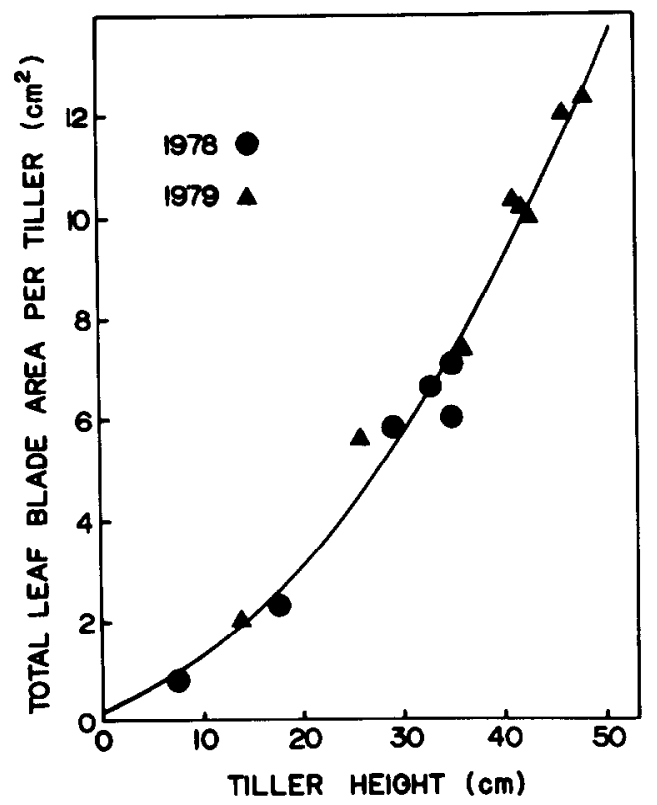

Fig. 7. Pinegrass total leaf blade area (y) as a function of tiller height $(x)$. Experimental points are means from 18 tillers. The smooth curve is the best fit second degree polynomial using data from both years: $y=$ $0.393747+0.0516038 x+0.00419223 x^{2}, S E_{y . x}=0.626, R^{2}=0.97$. 


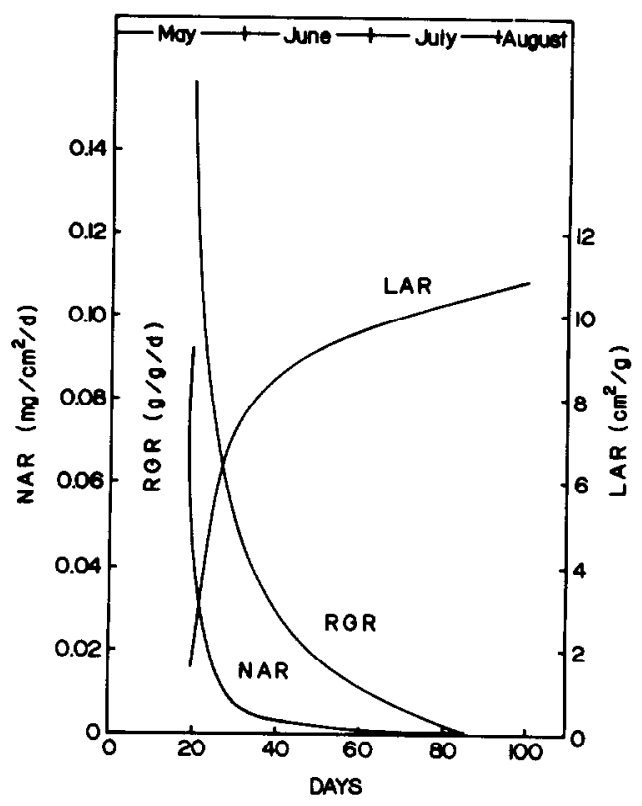

Fig. 8. Calculated growth analysis data from pinegrass in 1982. NAR = $(2.3891-0.027682 t) /\left(-442.484+25.8748 t-0.13787 t^{2}\right) . R G R=(2.3891-$ $0.027682 t) /\left(-29.8909+2.3891 t-0.013841 t^{2}\right) . L A R=R G R / N A R$.

related to an increase of 3 leaf characteristics: number of leaves per tiller (Fig. 4); individual leaf area (Fig. 5); and specific weight of leaves (Table 2). A tiller height increase accompanied this tiller weight increase (Fig. 2). The high correlation between tiller weight and tiller height indicated that tiller height can be used to predict tiller weight. These results agree with an earlier study that showed dry weight $\mathrm{m}^{-1}$ could be predicted by an equation using both tiller number ${ }^{-2}$ and tiller height (Stout et al. 1980).

The shape of an experimental growth curve is a function of ontogenesis, environment, and sampling (Sestak et al. 1971). Since environmental conditions varied during the period May to August, the growth pattern of pinegrass was expected to deviate from the potential pattern of pinegrass growth, and it is unlikely that the actual pattern would be a smooth curve. Nevertheless, pinegrass growth parameters were well predicted by a simple second degree polynomial. To estimate the time of growth cessation, the derived polynomials were differentiated, and the time when the change in the growth measure equalled zero was calculated. In 1978 zero growth rate was calculated to occur on day 62 ( 1 July) using leaf number data, day 69 ( 8 July) using tiller height data, and day 71 ( 10 July) using total leaf blade area data. In 1979 zero growth rate was calculated to occur on day 86 ( 25 July) using leaf number data, day 88 (27 July) using tiller height data, and day 92 (31 July) using leaf blade area data. In 1982 zero growth rate was calculated to occur on day 84 (23 July) using tiller height data, and on day 86 ( $25 \mathrm{July}$ ) using tiller weight data. The shorter time predicted from leaf number may be real since the exertion of leaves would be completed before completion of other measured growth parameters. It is interesting that independent measurements, such as leaf number, tiller height, leaf blade area, and tiller weight all predicted growth cessation at about the same time during a particular year. It is not known whether or not the time that the actual growth equals zero corresponds exactly with the time predicted from a best fit polynomial. However, the predicted time should be useful for comparison studies involving different treatments since it is based on all of the data taken during the growth period and is objective.

Growth analysis is a useful technique for providing a quantitative description of growth with physiological implications (Radford 1967). During the period 20 May to $20 \mathrm{July}$ in 1982, pinegrass had an average NAR of $0.005 \mathrm{mg} \mathrm{cm}^{-1} \mathrm{~d}^{-1}$ and an average $R G R$ of $0.029 \mathrm{~g} \mathrm{~g}^{-1} \mathrm{~d}^{-1}$. For comparison, 4-wk-old alfalfa (Medicago sativa L.) seedlings had an RGR of $0.006 \mathrm{~g} \mathrm{~g}^{-1} \mathrm{~d}^{-1}$, and 4-week-old birdsfoot trefoil (Lotus corniculatus L.) seedlings had an RGR of 0.006 $\mathrm{g} \mathrm{g}^{-1} \mathrm{~d}^{-1}$ when grown under low light intensities of 2153 to 8611 lux (Cooper 1967). Tobacco (Nicotiana tabacum L.) plants exposed to different levels of photosynthetically active radiation (24.9 and $\left.42.2 \mathrm{mE}^{-2} \mathrm{~d}^{-1}\right)$ in the field had relative growth rates of 0.137 and $0.162 \mathrm{~g} \mathrm{~g}^{-1} \mathrm{~d}^{-1}$ (Flynt et al. 1978). NAR of spring wheat (Triticum aestivum L.) cultivars varied from 0.54 to $0.60 \mathrm{mg} \mathrm{cm}^{-2} \mathrm{~d}^{-1}$, (Sestak et al. 1971). During a 13 wk growth period, RGR of annual sunflower (Helianthus annuus) decreased from $0.236 \mathrm{~g} \mathrm{~g}^{-1} \mathrm{~d}^{-1}$ to $0.070 \mathrm{~g} \mathrm{~d}^{-1}$ and NAR of annual sunflower decreased from 0.182 to $0.066 \mathrm{mg} \mathrm{cm}^{-2} \mathrm{~d}^{-1}$ (Sestak et al. 1971). Although direct comparison of growth analysis values for pinegrass to published values for other species is difficult owing to different temperatures and light intensities, pinegrass NAR and RGR (Fig. 8) were within the range reported for other $C_{3}$ plants. These preliminary growth analysis results indicate that this technique could be used in future studies involving treatment comparisons. The relationship established here between leaf blade area and tiller height can be used in these studies to provide an indirect but simple method of estimating leaf area.

The critical July herbage removal period (Stout et al. 1980) is not associated with any simple qualitative morphological stage or growth event. However, all measures of growth (leaf number, tiller height, tiller weight, and leaf blade area) indicate cessation of growth in July; thus agreeing with the preliminary conclusion that the initial period occurs at the time of growth cessation (Stout et al. 1980). Herbage removal during July caused maximum stand deterioration; however, herbage removal in May and June also decreased the stand, but to a lesser extent (Stout et al. 1980). NAR and RGR are larger in May and June than in July. Perhaps May-June herbage removal is less severe than July herbage removal because the plants can still photosynthesize and produce new plant tillers during this time.

Senescence of leaf blade area (Fig. 6) may partly account for the reported low nutrition value of pinegrass after 1 August (McLean et al. 1969) and low palatability by 15 August (McLean 1967).

\section{Conclusion}

This study provides a description of how pinegrass tillers grow vegetatively. The critical herbage removal period corresponds to a time when there is a general slowing down of all aspects of pinegrass growth, rather than with any distinct or qualitative growth stage. A relationship between tiller height and leaf area has been derived so that growth analysis studies can be done without doing time consuming and labor intensive leaf area measurements. Growth analysis revealed that pinegrass growing in the field shows growth characteristics that are typical for $\mathrm{C}_{3}$ plants. Since most aspects of pinegrass growth are correlated to tiller height, this simple measurement should be considered by range managers as a useful tool for evaluating pinegrass stand vigor and growth.

\section{Literature Cited}

Canadian Soil Survey Committee, Subcommittee on Soil Classification. 1978. The Canadian system of soil classification. Can. Dep. Agr. Pub. 1646. Supply and Services Canada, Ottawa, Ont.

Cooper, C.S. 1967. Relative growth of alfalfa growth of alfalfa and birdsfoot trefoil seedlings under low light intensity. Crop Sci. 7:176-178.

Flynt, R.W., D. Raper, and E.K. York. 1978. Comparative pre-floral growth of flue-cured tobacco in field and controlled environments. Agron. J. 70:555-559.

Freyman, S. 1970. Effects of clipping on pinegrass. Can. J. Plant Sci. 50:736-739.

McLean, A. 1967. Beef production on lodgepole pine-pinegrass range in southern British Columbia. J. Range Manage. 20:214-216.

McLean, A., S. Freyman, J.E. Miltimore, and D.M. Bowden. 1969. Evaluation of pinegrass as range forage. Can. J. Plant Sci. 49:351-359. 
Radford, P.J. 1967. Growth a nalysis formulae-their use and abuse, Crop Sci. 7:171-175.

Sestak, Z., J. Calsky, and P.G. Jarvis. 1971. Plant photosynthetic production manual of methods. Dr. W. Junk, N.V. Publishers, The Hague.

Stout, D.G., A. McLean, B. Brooke, and J. Hall. 1980. Influence of simulated grazing (clipping) on pinegrass growth. J. Range Manage. $33: 286-291$.
Stout, D.G., J. Hall, B. Brooke, and A. McLean. 1981. Influence of successive years of simulated grazing (clipping) on pinegrass growth. Can. J. Plant Sci. 61:939-943.

Tisdale, E.W., and A. McLean. 1957. The Douglas-fir zone of southern British Columbia. Ecol. Monogr. 27:247-266. 